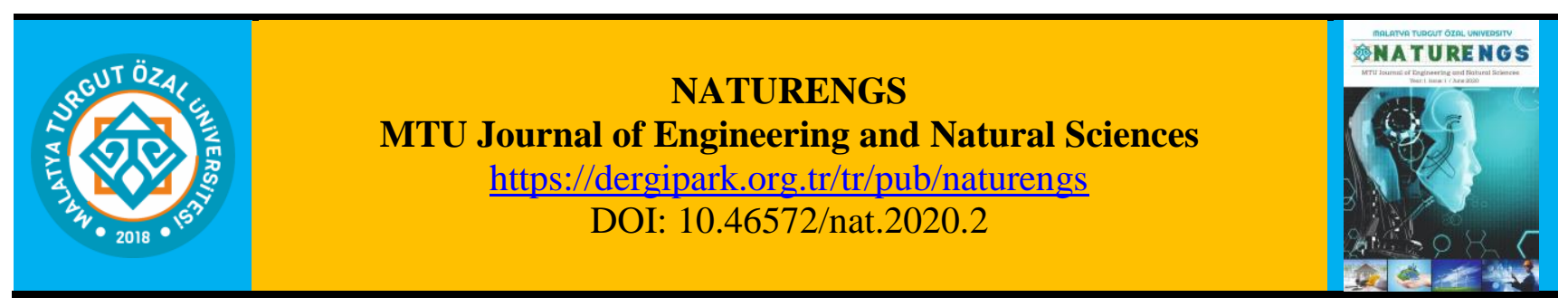

\title{
Temperature and Relative Humidity Models of the Malatya City
}

\author{
Ayse BİÇER \\ Department of BioEngineering, Faculty of Engineering and Natural Sciences, Malatya Turgut Özal University, \\ Malatya, Turkey.
}

(Received: 15.04.2020; Accepted: 02.05.2020)

\begin{abstract}
In this study, the temperature changes Malatya provinces located in the Euphrates Basin are analyzed and modeled based on 24 years of observation process (1996-2019). Relative humidity models were analyzed by observing the yearly mean temperatures of provinces, the lowest mean temperatures of winter months (December, January and February) and the highest mean temperatures of summer months (June, July and August). With the help of these models; temperature and humidity estimations can be made for future years and these models can be used in energy-related studies
\end{abstract}

Keywords: Temperature, Relative humidity, Meteorological data, Modelling.

\section{INTRODUCTION}

Meteorological data are of great importance in determining the energy potential of a region in the past and present, and developing ways to solve its problems [1,2]. The need for energy is directly related to climate and weather conditions. Climate data is of great importance in the design of buildings, in the planning of agricultural production, in the design of the energy and installations needed for heating residential and industrial areas in cold weather and cooling in hot weather. [3, 4].

Outdoor temperature values of cities and towns in Turkey were identified in the 1950s, yet they are not in compliance with the present day conditions. Population increase, green areas, industrialization and lakes and ponds created in the cities affect the climate structures of the cities and cause the change of the outdoor temperature parameter. Five large dams were constructed on the Firat River, which is one of the important rivers of Eastern Anatolia, from the border to the exit gateway for both energy production and irrigation. The Firat River is born on the Murat River and the Karasu River at an altitude of 3290 meters and flows through the cities of Erzincan, Tunceli, Elazığ, Malatya, Diyarbakir, Adiyaman, Gaziantep and Sanliurfa and flows into the Persian Gulf. Its length is $2800 \mathrm{~km}$ and a total of $6396 \mathrm{MW}$ of electrical energy is produced from five HEPPs through the river. This power is $30,8 \%$ of the electricity produced from hydroelectric power plants in Turkey, meeting $8,3 \%$ of the total electricity consumption. In addition to ensuring the energy generation of these dams, it also caused the change of the climate structure of the region. 
Many studies have been done on the subject, especially in the country. These studies can be grouped into two groups. The first group of studies are mainly related to climate structures. Some examples of these studies are summarized below:

Bakırc1 et al [1] conducted energy studies for Erzurum province using meteorological data. Çobany1lmaz and Yüksel [2] presented the case study of Ankara by examining the harms that cities can experience due to climate change. Turkey's climate classification structure was made by the General Directorate of Meteorology [3] -Department of Climatology. Dönmez [4] carried out studies involving cities' air conditioners and climates. Geymen and Dirican [5] analyzed sea-level changes due to climate change. Apple et al. [6] and Şen [7] developed weather forecasting models using meteorological values. Al-Garni et al. [8] examined the climatic structures of the eastern regions of Saudi Arabia and modeled the wind power of the region. Akpinar et al. [9] investigated the weather conditions and wind power of some provinces in the Eastern Anatolia Region. Bicer [10] established the temperature and humidity models using meteorological data for certain provinces in the Euphrates Basin.

The second group of studies deals with the effects of the artificial lakes or ponds on the climate of the region. Dam lakes in the region can be seen in Figure 1. Some of these studies are summarized below:

Şengün [11] examined the changes caused by Keban Dam Lake in Elazig climate within 30 years before and after 1975 and evaluated the results. Özkan [12] investigated the effect of Keban dam lake on Elazig climate conditions. He examined climate variables in the periods before and after the dam construction. After the dam was constructed, significant increases were observed in the winter months, as well as a certain amount of decreases in the temperatures in the summer months. Yeşilata et al. [13] investigated the change in the dam lake caused by temperature and humidity parameters in the GAP Region. Apart from these studies, Emiroglu et al. [14], Tonbul [15] and Kadığlu [16] investigated the effect of Keban Dam Lake on the climate structure of Şanlıurfa province, Elazig province, Biçer and Yıldız [17]. Bacanlı and Tuğrul [18] examined the effect of Gökpınar Dam Lake on the climate structure of the provinces.

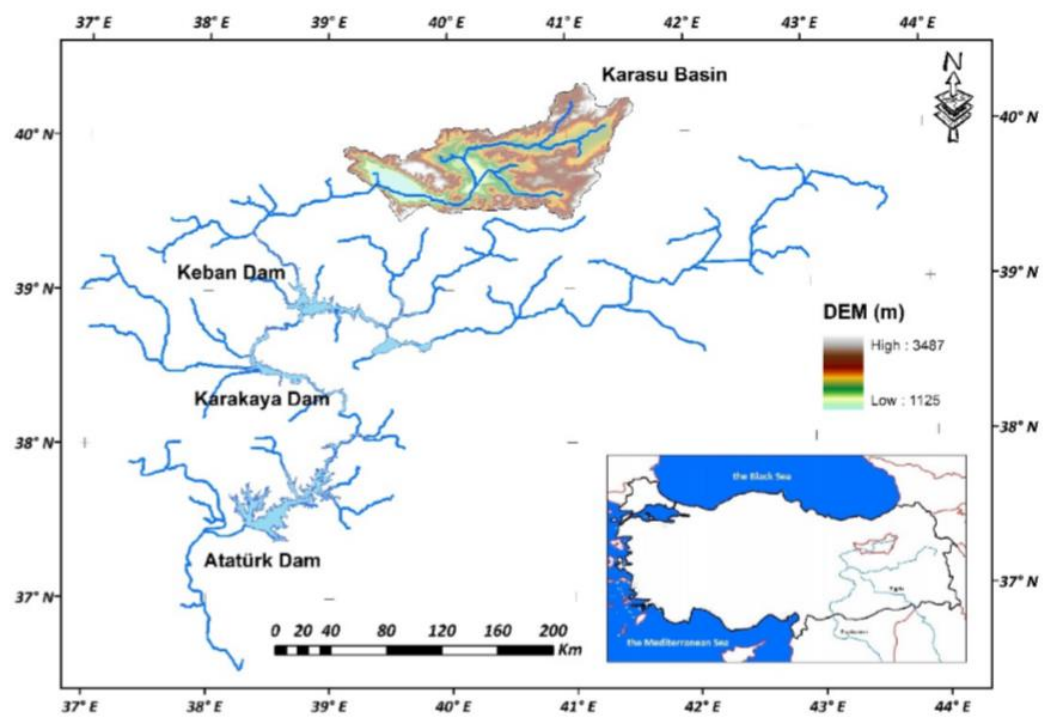

Figure 1. Some of the dam lakes in the Upper Euphrates basin [19] 
The aim of this study is to examine the weather parameters such as temperature and humidity of Malatya province by using meteorological values for a 24-year observation period, as well as presenting a preliminary idea for future studies by determining regression equations.

\section{MATERIAL AND METHODS}

\subsection{Materials}

The outdoor temperature parameter $(\mathrm{T})$ of Malatya province, along with the monthly lowest and highest average temperature values were taken from the results of the meteorological measurement of the General Directorate of State Meteorological Affairs for the 1996-2019 observation process [20].

\subsection{Methods}

\subsubsection{Temperature}

The average of the lowest monthly average of temperatures $\left(\mathrm{T}_{\mathrm{dmin}}\right)$ for the winter months (December, January and February) of the province is calculated by Equation (1) and the average of the lowest temperature averages (EDSO) for the observation process [21].

$\mathrm{T}_{\mathrm{dmin}}=\left(\mathrm{T}_{\min \text { December }}+\mathrm{T}_{\min \text { January }}+\mathrm{T}_{\min \text { February }}\right) \cdot(1 / 3)$

$\mathrm{T}_{\mathrm{EDSO}}=(1 / \mathrm{n}) \cdot \sum \mathrm{T}_{\text {dmin }}$

Similarly, for the summer season (June, July and August), the average of the highest temperature values of the province $\left(\mathrm{T}_{\mathrm{dmax}}\right.$ ), Equation (3) and the average of the highest temperature values for the observation process (TEYSO) were calculated by Equation (4) [21].

$\mathrm{T}_{\mathrm{dmaks}}=\left(\mathrm{T}_{\max \text { June }}+\mathrm{T}_{\max \text { July }}+\mathrm{T}_{\text {maks August }}\right) .(1 / 3)$

$\mathrm{T}_{\mathrm{EYSO}}=(1 / \mathrm{n}) . \sum \mathrm{T}_{\mathrm{dmax}}$

Using the meteorological values of each province, the average of the lowest temperature averages (SO) of the 12 months of the year for the 24-year observation period was calculated through Equation (5)...

$\mathrm{T}_{\mathrm{SO}}=(1 / \mathrm{n}) . \sum \mathrm{T}_{\text {yearly }}$

\subsubsection{Relative Humidity}

The monthly average values of the relative humidity parameter of the province were calculated through the annual meteorological measurement results of the General Directorate of State Meteorological Affairs for the 1996-2019 observation process [20]. 


\section{RESULTS AND DISCUSSION}

The average change of EDSO, EYSO and SO temperature averages of the province is shown in Figure 2 for the monthly period and 24-year observation period. For this process, the average temperature, January, February and December temperature average values (EDSO), June, July and August temperature average values (EYSO) and 12-month average temperature values (SO) are shown in Table 1 as allocated by provinces.

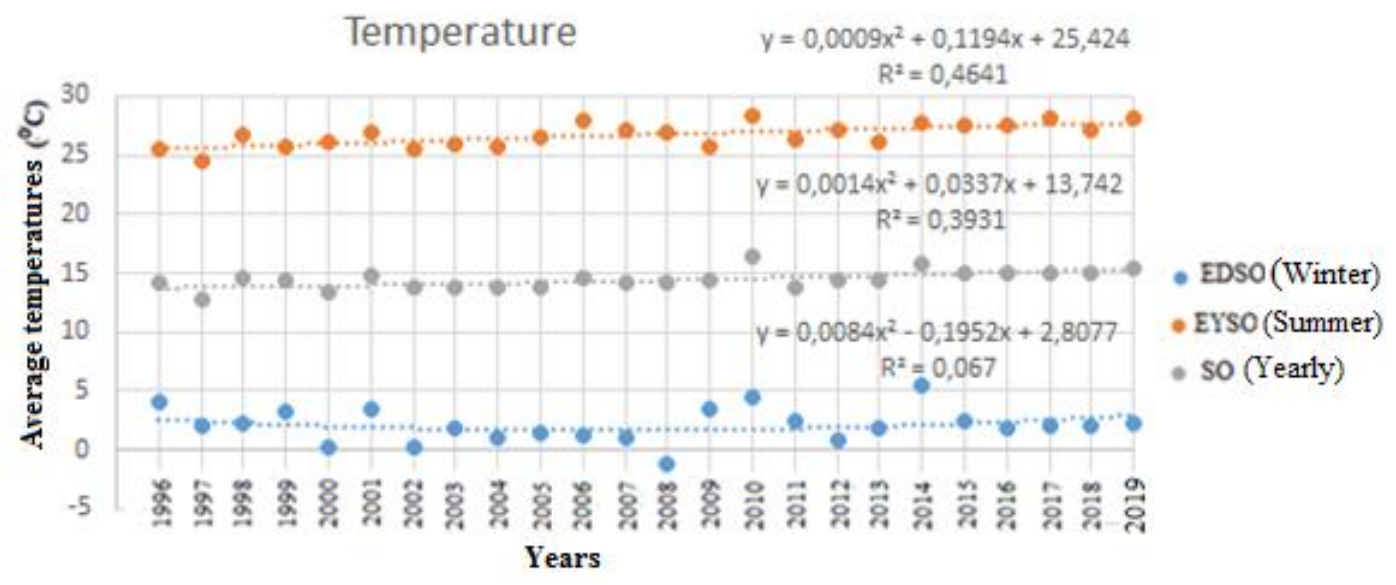

Figure 2. Linear regression of average temperature values of Malatya province

Table 1. Average temperature values of Malatya province $\left({ }^{\circ} \mathrm{C}\right)$

\begin{tabular}{|c|c|c|}
\hline \multicolumn{3}{|c|}{ Average temperature values } \\
\hline EDSO & EYSO & SO \\
\hline 2.07 & 26.7 & 14.4 \\
\hline
\end{tabular}

Examining Figure 2, it can be seen that the smallest value of EDSO was observed in 2008 ($\left.1.23{ }^{\circ} \mathrm{C}\right)$, the highest value in $2010\left(4.57^{\circ} \mathrm{C}\right)$, the lowest value of EYSO in $1997\left(24.47{ }^{\circ} \mathrm{C}\right)$ and the highest value in $2010\left(28,43^{\circ} \mathrm{C}\right)$. Likewise, the smallest value for SO was observed in 1997 $\left(12.81{ }^{\circ} \mathrm{C}\right)$ and the highest value in $2010\left(16.34{ }^{\circ} \mathrm{C}\right)$. The regression equations of these three parameters over the years show a rising graph, albeit very small. Keban Dam, which formed a lake field in 1975, and Karakaya Dam Lake in 1988 brought cooling to Elazig province for 4-5 ${ }^{\circ} \mathrm{C}$ in winter conditions and 2-3 ${ }^{\circ} \mathrm{C}$ in summer conditions [10]. However, both global warming and the explosions in the Sun caused a temperature rise across the world. For this reason, during the observation, the average temperature of Malatya province has risen slightly in 24 years.

EDSO, EYSO and SO temperature variation models of the province were determined by linear regression relations on the computer. The temperature changes of the province were examined as linear, exponential, polynomial and logarithmic models, and the equation with the largest $\mathrm{R}^{2}$ value among the models was determined as the model of the relevant parameter of that province. Table 2 shows the models shown collectively and $\mathrm{R}^{2}$ of the model. In this table, the model suitable for the changes in the average temperatures of the province is stated in bold. Examining these models, it can be seen that EDSO, EYSO and SO exchange models of the province are polynomial models 
Table 2. Temperature values linear regression relations of Malatya province

\begin{tabular}{|c|c|c|c|}
\hline Model type & SO & EDSO & EYSO \\
\hline Linear & $\mathrm{T}_{\mathrm{SO}}=0,07 * \mathrm{Y}+13,6$ & $\mathrm{~T}_{\mathrm{EDSO}}=0,015^{*} \mathrm{Y}+1,89$ & $\mathrm{~T}_{\mathrm{EYSO}}=0,097 * \mathrm{Y}+25,6$ \\
& $\mathrm{R}^{2}=0,3868$ & $\mathrm{R}^{2}=0,0049$ & $\mathrm{R}^{2}=0,4626$ \\
\hline Exponential & $\mathrm{T}_{\mathrm{SO}}=13,59 * \mathrm{e}^{0,0} 048^{*} \mathrm{Y}$ & - & $\mathrm{T}_{\mathrm{EYSO}}=25,527 * \mathrm{e}^{0,0036^{*} \mathrm{Y}}$ \\
& $\mathrm{R}^{2}=0,3832$ & & $\mathrm{R}^{2}=0,4625$ \\
\hline Polynomial & $\mathrm{T}_{\mathrm{SO}}=0,001 * \mathrm{Y}^{2}+0,03 * \mathrm{Y}+13$ & $\mathrm{~T}_{\mathrm{EDSO}}=0,009 * \mathrm{Y}^{2}-0,2 * \mathrm{Y}+2$ & $\mathrm{~T}_{\mathrm{EYSO}}=0,001^{*} \mathrm{Y}^{2}+0,12 * \mathrm{Y}+25$ \\
& $\mathrm{R}^{2}=0,3931$ & $\mathrm{R}^{2}=0,0741$ & $\mathrm{R}^{2}=0,4641$ \\
\hline Logarithmic & $\mathrm{T}_{\mathrm{SO}}=0,52 * \operatorname{Ln}(\mathrm{Y})+13,3$ & $\mathrm{~T}_{\mathrm{EDSO}}=0,13 * \operatorname{Ln}(\mathrm{Y})+2,8$ & $\mathrm{~T}_{\mathrm{EYSO}}=0,76^{*} \operatorname{Ln}(\mathrm{Y})+24,97$ \\
& $\mathrm{R}^{2}=0,2969$ & $\mathrm{R}^{2}=0,0053$ & $\mathrm{R}^{2}=0,4024$ \\
\hline
\end{tabular}

T=Temperature, , Y=Year

Relative humidity is the ratio of the humidity in the air to the maximum humidity at that temperature. The relative humidity must exceed $100 \%$ in order for precipitation to occur somewhere. The relative humidity decreases as the temperature increases. The reason for this is that the increase in the volume of the heated air will increase the humidity it can take. As relative humidity decreases, evaporation increases, while, on the other hand, relative humidity increases, evaporation decreases. Examining Table 3, the smallest and largest average relative humidity values between $1996-2019$ can be seen as $46.55 \%-57.51 \%$ for Malatya province. The average relative humidity change by years is shown in the graph in Figure 3.

Table 3. Average relative humidity values of the Malatya province

\begin{tabular}{|c|c|c|c|}
\hline Years & Relative humidity & Years & Relative humidity \\
\hline 1996 & 56.94 & 2008 & 52.56 \\
\hline 1997 & 53.83 & 2009 & 56.7 \\
\hline 1998 & 53.13 & 2010 & 50.06 \\
\hline 1999 & 49.17 & 2011 & 49.63 \\
\hline 2000 & 48.08 & 2012 & 50.05 \\
\hline 2001 & 47.4 & 2013 & 46.65 \\
\hline 2002 & $\underline{\mathbf{5 7 . 5 1}}$ & 2014 & 46.88 \\
\hline 2003 & 58.45 & 2015 & 50.78 \\
\hline 2004 & 56.67 & 2016 & 46.59 \\
\hline 2005 & 56.21 & 2017 & $\mathbf{4 6 . 5 5}$ \\
\hline 2006 & 54.23 & 2018 & 46.56 \\
\hline 2007 & 54.09 & 2019 & 46.60 \\
\hline
\end{tabular}

In the average relative humidity equations and curves shown in Figure 3, it can be conferred that the appropriate model is polynomial type as in the temperature parameter and the equation shows a decreasing trend with the (-) sign at the beginning of the equation (Table 4). 


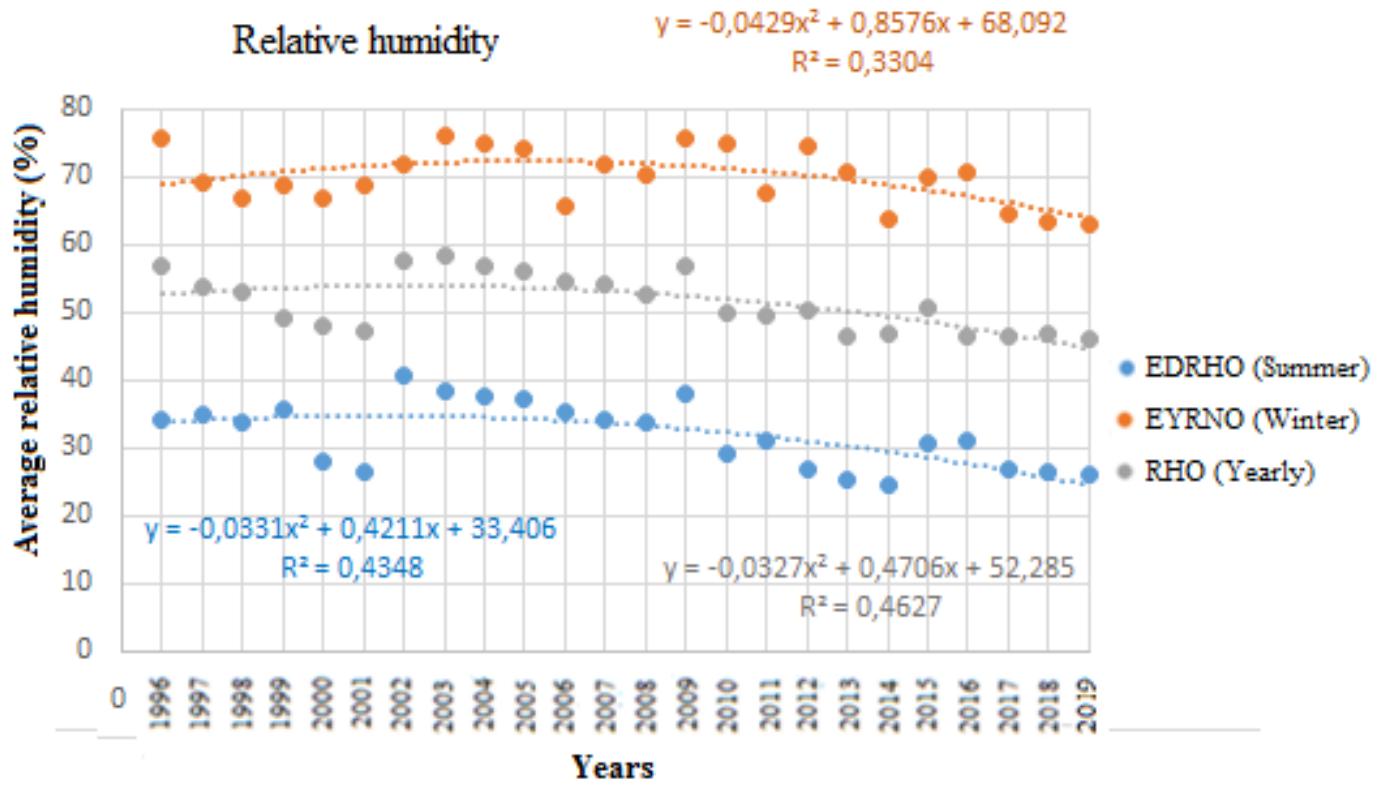

Figure 3. Linear regression of the relative humidity values of Malatya province

Here; EDRHO: the smallest average relative humidity, EYRHO; the largest average relative humidity and RHO: the relative humidity averages of the 12 months (yearly)

Table 4. Average relative humidity values of the province, linear regression equations

\begin{tabular}{|l|c|c|c|}
\hline Model type & RHO & EDRHO & EYRHO \\
\hline Linear & $\mathrm{RHO}=-0,35 * \mathrm{Y}+55,8$ & EDRHO $=-0,406 * \mathrm{Y}+36,99$ & EYRHO $=-0,215 * \mathrm{Y}+72,7$ \\
& $\mathrm{R}^{2}=0,3456$ & $\mathrm{R}^{2}=0,347$ & $\mathrm{R}^{2}=0,1312$ \\
\hline Exponential & $\mathrm{RHO}=55,87 * \mathrm{e}^{-0,000 * \mathrm{Y}}$ & EDRHO $=37,13 * \mathrm{e}^{-0,0} 13^{*} \mathrm{Y}$ & EYRHO $=72,746^{*} \mathrm{e}^{-0,003 * \mathrm{Y}}$ \\
& $\mathrm{R}^{2}=0,3523$ & $\mathrm{R}^{2}=0,3554$ & $\mathrm{R}^{2}=0,1374$ \\
\hline Polynomial & $\mathrm{RHO}=-0,03 * \mathrm{Y}^{2}+0,5 * \mathrm{Y}$ & $\mathrm{EDRHO}=-0,03 * \mathrm{Y}^{2}+0,42 * \mathrm{Y}$ & $\mathrm{EYRHO}=-0,04 * \mathrm{Y}^{2}+0,9 * \mathrm{Y}$ \\
& $+52,3 \quad \mathrm{R}^{2}=0,4627$ & $+33,4 \quad \mathrm{R}^{2}=0,4348$ & $+68,1 \quad \mathrm{R}^{2}=0,3304$ \\
\hline Logarithmic & $\mathrm{RHO}=-2,37 * \operatorname{Ln}(\mathrm{Y})+57$ & EDRHO $=-2,61 * \operatorname{Ln}(\mathrm{Y})+37,9$ & EYRHO $=-1,32 * \operatorname{Ln}(\mathrm{Y})+73$ \\
& $\mathrm{R}^{2}=0,2223$ & $\mathrm{R}^{2}=0,1979$ & $\mathrm{R}^{2}=0,4024$ \\
\hline
\end{tabular}

The models that are found in compliance among the temperature and humidity models examined in the province are given collectively in Table 5.

Table 5. Linear regression relations of the city's temperature and relative humidity values

\begin{tabular}{|c|c|l|}
\hline Climate Parameter & Season & \multicolumn{1}{c|}{ Linear regression models } \\
\hline $\begin{array}{c}\text { Temperature } \\
(\boldsymbol{(} \mathbf{C})\end{array}$ & $\mathrm{SO}$ & $\mathrm{T}_{\mathrm{SO}}=0,0014 * \mathrm{Y}^{2}+0,0337 * \mathrm{Y}+13,742$ \\
\cline { 2 - 3 } & $\mathrm{EDSO}$ & $\mathrm{T}_{\mathrm{EDSO}}=0,0088 * \mathrm{Y}^{2}-0,2028+2,8327$ \\
\cline { 2 - 3 } & $\mathrm{EYSO}$ & $\mathrm{T}_{\mathrm{EYSO}}=0,0009 * \mathrm{Y}^{2}+0,1194 * \mathrm{Y}+25,42$ \\
\hline $\begin{array}{c}\text { Relative humidity } \\
(\%)\end{array}$ & $\mathrm{RHO}$ & $\mathrm{RHO}=-0,0327 * \mathrm{Y}^{2}+0,47 * \mathrm{Y}+52,28$ \\
\cline { 2 - 3 } & $\mathrm{EDRHO}$ & $\mathrm{RDRHO}=-0,0331 * \mathrm{Y}^{2}+0,4211 * \mathrm{Y}+33,406$ \\
\cline { 2 - 3 } & $\mathrm{EYRHO}$ & $\mathrm{T}_{\mathrm{EYNO}}=-0,0429 * \mathrm{Y}^{2}+0,8576 * \mathrm{Y}+68,092$ \\
\hline
\end{tabular}




\section{CONCLUSIONS}

In this study, using the meteorological data for the 24-year observation process of the Malatya province in the Upper Euphrates basin, the models of the change of the temperature average and relative humidity parameters of the provinces were determined.

A polynomial equation model has been determined for the average of average annual temperature and humidity in winter, as well as the lowest, the highest in summer and 12 months during the city's observation.

$\checkmark$ The average temperature of the province shows a rising change while the relative humidity shows a lowering change.

With these equations, it will be possible to estimate the temperature averages and relative humidity parameters of the province in the coming years and to determine the effects of these predicted weather conditions on the environment.

Outdoor temperature parameter, which is an important parameter in the design of heating installations, has been calculated based on very old data. Outdoor temperature parameters must be updated due to the increase in the winter months of the province considering the dam lakes in the region and the global warming. This study will help update the outdoor temperature parameter for the summer and winter seasons across the country.

Both construction costs and energy costs will be reduced with the design of the heating installations to be prepared with the new outdoor temperature parameter to be updated.

Thanks to: I would like to take this chance to thank the "General Directorate of State Meteorological Affairs" for their interest and assistance for the provision of meteorological measurement data used in the study.

\section{REFERENCES}

[1] Bakırcı, K., Özyurt, Ö., Yılmaz, M.and Erdoğan, S. (2006). Erzurum ili enerji çalışmaları için iklim ve meteoroloji verileri, Tesisat Mühendisliği Dergisi, 9: 19-26.

[2] Çobanyılmaz, P. And Yüksel, Ü.D. (2013). Kentlerin iklim değişikliğinden zarar görebilirliğinin belirlenmesi: Ankara Örneği, Süleyman Demirel Üniversitesi Fen Bilimleri Enstitüsü Dergisi, 17(3): 389-50.

[3] İklim Sınıflandırmaları, (2017). Meteoroloji Genel Müdürlüğü, Klimatoloji Şube Müdürlüğü, Kalaba, 1-16, Ankara, Türkiye.

[4] Dönmez, Y. (1984). Umumi klimatoloji ve iklim çalışmaları İ.T.Ü. Yayın No: 2506.

[5] Geymen, A. and Dirican, A.Y. (2016). İklim değişikliğine bağlı deniz seviyesi değişiminin coğrafi bilgi sistemleri kullanılarak analiz edilmesi, Harita Teknolojileri Elektronik Dergisi, 8(1): 65-74.

[6] Apple, L.S.C., Chow, T.T., Square, K.F.F. and Lin, J.Z. (2006). Generation of a typical meteorological year for Hong Kong. Energy Conversion and Management, 47: 87-96. 
[7] Sen, Z. (1999). Simple nonlinear solar irradiation estimation model. Renewable Energy, 32:342-350.

[8] Al-Garni, A.Z., Şahin, A.Z. and Al-Farayedhi, A. (1999). Modelling of weather characteristics and wind power in the Eastern Part of Saudi Arabia, International Journal of Energy Research, 23: 805-812.

[9] Akpınar, E.K., Biçer, Y., Erdoğan, B. and Çetinkaya, F. (2005). Doğu Anadolu Bölgesindeki bazı illerin hava şartları ve rüzgar gücünün araştırılması. 15. Ulusal Isı Bilimi ve Tekniği Kongresi 7-9 Eylül, Karadeniz Teknik Üniversitesi, Trabzon.

[10] Bicer, A. (2019). Firat havzasında bulunan bazı illerin sıcaklık ve nem modelleri, Bartın University International Journal of Natural and Applied Sciences, 2(1): 50-58.

[11] Şengün, M.T. (2007). Son değerlendirmeler ışığında Keban Barajı'nın Elazığ İklimine etkisi. Doğu Anadolu Bölgesi Araştırmaları, 116-121.

[12] Özkan, F. (1996). Keban Baraj Gölü’nün Elazığ Bölgesi iklim şartlarına etkisinin araştırılması, Yüksek Lisans Tezi, Frrat Üniversitesi Fen Bilimleri Enstitüsü, Elazı̆̆.

[13] Yeşilata, B., Bulut, H. and Yeşilnacar, M.İ. (2004). GAP Bölgesinde sıcaklık ve nem parametrelerindeki baraj gölü kaynaklı değişim trendinin araştırılması. Tesisat Mühendisliği Dergisi, 83: 21-31.

[14] Emiroğlu, M. E., Özkan, F. and Öztürk, M. (1996). Keban Barajı Rezervuarı'nın Elazığ ili iklim şartlarına etkisi üzerine bir araştırma. GAP I. Mühendislik Kongresi Bildiriler Kitabı, Sayfa 167-174, Harran Üniversitesi, Şanliurfa.

[15] Tonbul, S. (1986). Elazı̆̆ ve çevresinin, iklim özellikleri ve Keban barajının yöre iklimi üzerine olan etkileri. Fırat Üniversitesi Coğrafya Sempozyumu, 14-15 Nisan, Elazı̆̆.

[16] Kadığlu, M. (1994). Keban Barajı öncesi ve sonrasında çevre ikliminin Franktal analizi. Bayındırlık ve İskan Bakanlığı DSİ Genel Müdürlüğ̈̈ Su ve Toprak Kaynaklarının Geliştirilmesi Konferansı Bildirileri 3: 1087-1098, Ankara.

[17] Biçer, Y. and Yıldız, C. (1994). Atatürk Barajı Rezervuarının Şanlıurfa ili dış sıcaklık parametresine etkisinin araştırılmas1, 3. Ulusal Soğutma ve İklimlendirme Kongresi, Sayfa 333-340, 4-6 Mayıs Çukurova Üniversitesi , Adana.

[18] Bacanlı, Ü.G. and Tuğrul, A.T. (2016). Baraj göllerinin iklimsel etkisi ve Vali Recep Yazıcıoğlu Gökpınar Baraj gölü örneği. Pamukkale Üniversitesi Muh Bilim Dergisi 22(3): 154-159.

[19] Uysal, G., Şorman, A.A. and Şensoy, A. (2016). Streamflow Forecasting Using Different Neural Network Models with Satellite Data for a Snow Dominated Region in Turkey, Procedia Engineering 154: 1185-1192.

[20] MGM, (2019). Devlet Meteoroloji İşleri Genel Müdürlüğü, aylık ve yıllık meteorolojik ölçüm değerleri, 23 Şubat 2019.

[21] Gülferi, İ. (1976). Meteorolojik değerler yardımıyla kış için dış hesap sıcaklığının bulunmasında yeni bir istatistiki metot. Doktora Çalışması, İTÜ Fen Bilimleri Enstitüsü. 